\title{
Performance on the Work-related Stress and Job contentment of Primary School Teachers of Government and Private Sectors
}

\author{
Harish.K.A, B.Jeya Prabha
}

\begin{abstract}
Teachers have the majority of ingenious personnel and they are not only consider to schools as well as colleges although to for our society. They are shaping the people by their powerful intervention in the life of students. Stress is considered unavoidable in one's life due to excessive and an increasing workload which leads to complex and multiple dimensional problems in our everyday life of oneself. The world is off-late is said to be a scope of achievement alongside world of stress. Stress is found to be with everyone and at everywhere, starting from our own family, the community circle that we belong to, the society around us and above all the place of work that we're in. Right form birth to death, each and every individual is exposed to stress. The current experimental investigation is discovered the relevant issues corresponding for the stress through job as well as the level of the precaution safety between teachers through reviewing correspondent literatures by earlier results. The example volume of $N$ is 500 is considered also the example recognized population of Chennai teachers as well as its periphery of together private as well as government schools. It is understood through earlier studies as well as investigation so as to stress between teachers has huge level in the current scenario. Hence, the authorities need gets awareness those issues of stress as well as suitable action taken for necessary steps to cope familiar with the changing lives in order to enhance the productivity of the teaching community which is the need of the hour.
\end{abstract}

\section{INTRODUCTION}

Life has become very tough due to the increasing cutthroat competition that induces the employer to implement tough policies, practices and systems that could make the employer survive against all/any type of complex situations and complexities. Stress, in a mankind, no doubt, disturbs the normal functioning of the human system. Stress is caused due to excessive workload.

Robinson (2007) in his perception and purview characterizes, Stress as a pressure of unpropitious impacts that destroys the regular balance of the physiological motions of the body due to inevitable stressors caused. Malow-Iroff and Johnson (2006), in their findings have inferred that stress is an individual reaction to the various kinds of biological happenings, cooperation with others and to the natural environmental conditions.

Revised Manuscript Received on June 22, 2019.

Harish.K.A, Research Scholar, Department of Management Studies, Vel Tech High Tech Dr. Rangarajan Dr. Sakunthala Engineering College, Avadi, Chennai - 600062, Tamil Nadu, India

B.Jeya Prabha, Professor, School of Management, Vel Tech Dr.RR Dr.SR University, Avadi, Chennai - 600062, Tamil Nadu, India.
Occupational stress is caused due to an individual person characteristic, attitude and his/her behavior to changing situations. The situations or the incidents caused may be different at different times and the intensity of the conflict or the stressor may be different.

Authors (Zhang, 2007, Betoret, 2006; Lazuras, 2006; Grebennikov and Wiggins, 2006 Jepson and Forrest 2006, Tytherileigh, Webb, Cooperand Ricketts, 2005; Bachkirova, 2005; Ahmad, Raheem Jamal 2003; Hansen Sullivan 2003; in their studies have explained in detail about the reaction of the individual to these changing conditions

Traditionally, it was felt that Teaching, a profession of low stress and peaceful occupation (French et al., 1982). The fact in the last couple of decades has tremendously changed and made people feel unbelievable (Olivier \& Venter, 2003). A famous saying goes this way, A priest says that my entire life is praying you, A doctor says that my life is serving his patients, A teacher says that apart from teaching, there are other such duties to perform such as Admission Duty, Attendance record, Result Analysis, Office work, Administrative work, Social Work, Revaluation work, Conducting practical trainings and placements, to take care of college magazine, research and development activities, intra/inter level student events, class committee works, examination duties, assignments, paper checking and paper setting works, counselling, to conduct remedial classes, to take care of discipline etc., In addition to it, teachers have to stay 2-4 hours after work hours for additional work as designated by the higher authorities. Teaching profession is felt pity and lives through hell on earth (Schonfield, 1990).

Borg (1990) exposed the fact so as to nearly one-third of the teachers have felt that teaching profession as heavily stressful. As indicated above, teachers in their profession are exposed to various factors leading to physiological and mental stress. Kyriacou (2001), in his study has indicated that student behavior and discipline in the classroom, challenging relationships with colleagues, poor working environment, improper role clarity and job insecurity are the factors that lead to stress.

Capel 1987, Cooper 1986, Pierce and Molly 1990 have in their research studies have evidentally indicated that health of an human is being highly affected and deteriorated due to work or job related stressors. On the other hand, authors (Eckles, 1987; Quick and Quick, 1984) have identified stressors such as Mental Disorder, Deterioation of health leading to poor teaching performance, dissatisfaction in job, 


\section{Private Sectors}

irregularity in work, improper decision making and mishandling of the situation occurs a important role in the increase of stress among the teaching fraternity. Across the universe, the effect of stress and its impact on the teaching fraternity has been an area of concern thus leading the teaching fraternity to end up their career at a very early stage of their career. It is because of these concerns the study of the necessity of stress relieving factors becomes the need of the hour today for a better tomorrow.

\section{IMPORTANCE OF THE STUDY}

Teachers are the assets of the nation, they build the nation, they develop the skills and the talent which the nation requires, they are always an inevitable resource without whom, any nation cannot survive. The economist, the strategist, the financeist or an entrepreneur are nurtured by the fundamental qualities that the teacher poses on the student in the initial stages. The society is shaped, formulated and modernized only by the teaching community because it is they who frame the policies of the education system and strive hard to deliver the best of its services to the individual and to the nation. The teachers always are known as the strongest pillars of the nation due to their social interest towards the development of the individual which is driven to the society, thereby extending the same services to the nation. They cannot be neglected by anyone. They do the nation building exercise. A country cannot survive nor progress without best teachers. They influence the young minds in various forms. The great minds of this world are from the mightier souls and hands of a teacher. It is a pity to see that a majority of the teaching fraternity are not successful or happy in their personal life. On one hand, the teachers develop a bunch of successful pirates to this nation but they find themselves to turn successful due to the various unforeseen factors, the teaching fraternity witnesses such as remuneration, participation, quality of work life, job security, work challenge, recognition and status, opportunity for growth and supportive relationships.

\section{PROBLEM STATEMENT}

Teacher Retention is a serious issue today in most of the places. Due to excessive physical and mental workload, the profession of teaching has become drained and sustainability of teachers has become the focal point with the need of the hour being to develop unstressful policies and practices. Teachers also tend to be highly stressful due to poor working conditions, lack of motivation and morale, No unity of command and direction, Improper remuneration of personnel, job insecurity, no proper scalar chain in allocation of authority and responsibility.

While taking literatures, its contract by means of stresses issues in common and still in limelight, the stress isues that related with its gender; level of grade or else experience. Consequently, the reason of our research is for analyzing a structure that would permit the higher positions to supervise and control the lower levels within the bureaucracy. The study would also emphasize and examine stress through the fundamentals of the job-related stress by means of satisfaction level together government as well as private sector teachers.

\section{AIMS OF OUR STUDY}

For studying and analyze various sources of job stressors inducing the teachers of the private and the government schools.

$>$ To assess the impact of the various sources of work stressors that affects working teachers form the government as well as private sectors

$>$ For determining level of various stressors influencing stress between the male as well as the teachers of female from the primary and government schools.

$>$ To analyze the inter-relationships between the teachers working in government and the private sectors on account of various sources of stress.

\section{DATA ANALYSIS AND INTREPRETATIONS}

\section{Table. 1 Level of work related pressure of the primary} school teachers

Work Related Pressure among the primary school teachers

\begin{tabular}{|l|l|l|l|}
\hline Sno & $\begin{array}{l}\text { Level of Work } \\
\text { Related Pressure }\end{array}$ & Sample & Percentage \\
\hline 1 & $\begin{array}{l}\text { Stress level found to } \\
\text { be at high level }\end{array}$ & 195 & 65 \\
\hline 2 & $\begin{array}{l}\text { Stress level found to } \\
\text { be moderate }\end{array}$ & 60 & 20 \\
\hline 3 & $\begin{array}{l}\text { Stress level found to } \\
\text { be at low level }\end{array}$ & 45 & 15 \\
\hline & TOTAL & $\mathbf{3 0 0}$ & $\mathbf{1 0 0}$ \\
\hline
\end{tabular}

Figure 1 shows the stress by occupational level along with the teachers from school.

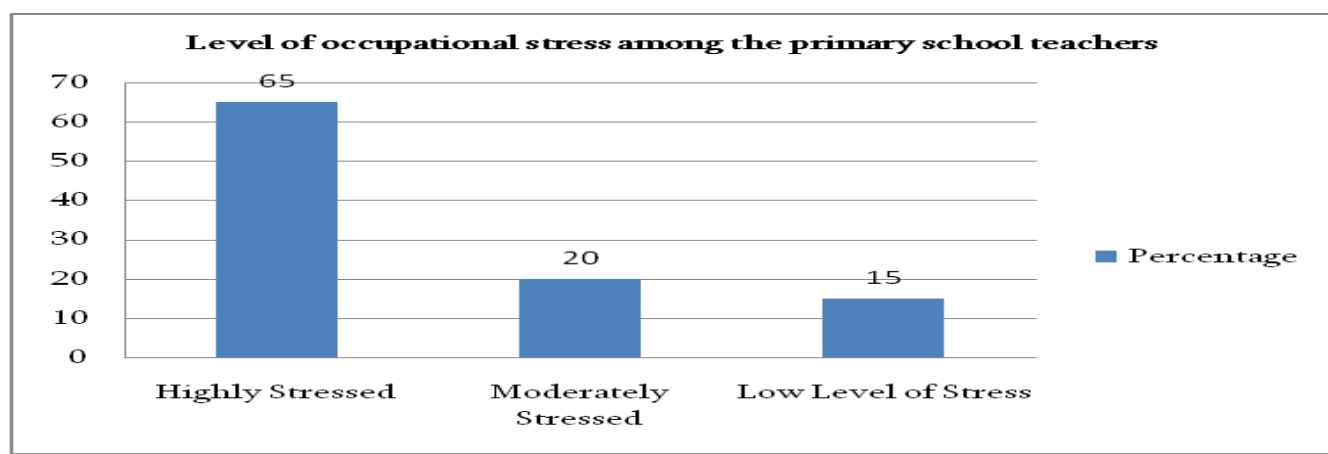

Fig. 1 stress by occupational level along with the teachers from school 
It is derived from the above table that the quantity of elementary teachers who are observed to be in very distressing condition is around $65 \%$. This infers that there is negligible level of job stress between the teachers of the elementary schools denoting that the null hypothesis is rejected.

Table. 2 Table indicating the level of stress among the teachers from primary private as well as government school.

Mean; Standard Deviation \& value of $t$ teachers from government as well as private school.

\begin{tabular}{|l|l|l|l|l|l|l|}
\hline Sno & Category & Sample & Mean & $\begin{array}{l}\text { Standard } \\
\text { Deviation }\end{array}$ & t-value & $\begin{array}{l}\text { Level } \\
\text { significance }\end{array}$ \\
\hline 1 & Private & 150 & 61.42 & 3.82 & 2.16 & 0.05 \\
\hline 2 & Government & 150 & 44.7 & 2.11 & & \\
\hline
\end{tabular}

Figure 2 shows the standard deviation of the teachers from the school of government as well as private sector.

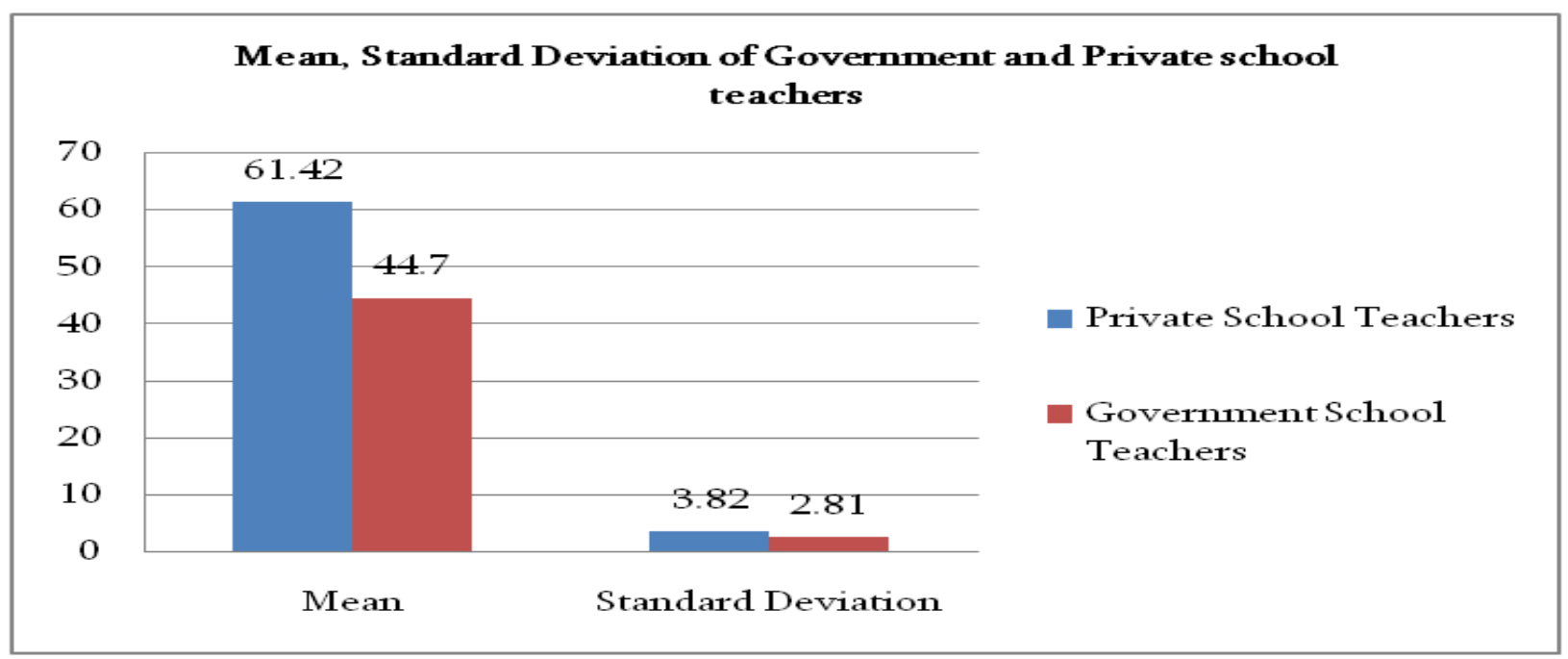

Fig.2 Standard deviation of the teachers from the school of government as well as private sector

It is seen that from the above table that the value of $\mathrm{t} 2.16$, more observed by the primary school teachers compared to that noteworthy at the level 0.05 . This infers that the stress is the government school teachers.

Table. 3 Table showing level of stress male as well as female primary school teachers.

Mean and Standard Deviation and value of " $t$ " for male as well as female teachers from school of primary. Teachers

\begin{tabular}{|c|c|c|c|c|c|c|}
\hline Sno & Category & Sample & Mean & $\begin{array}{c}\text { Standard } \\
\text { Deviation }\end{array}$ & t-value & $\begin{array}{c}\text { Level of } \\
\text { significance }\end{array}$ \\
\hline 1 & Male & 150 & 52.26 & 8.17 & 0.15 & Not significant \\
\hline 2 & Female & 150 & 55.3 & 9.07 & & \\
\hline
\end{tabular}

Figure 3 shows the mean standard devition of male and female teacher from primary school.

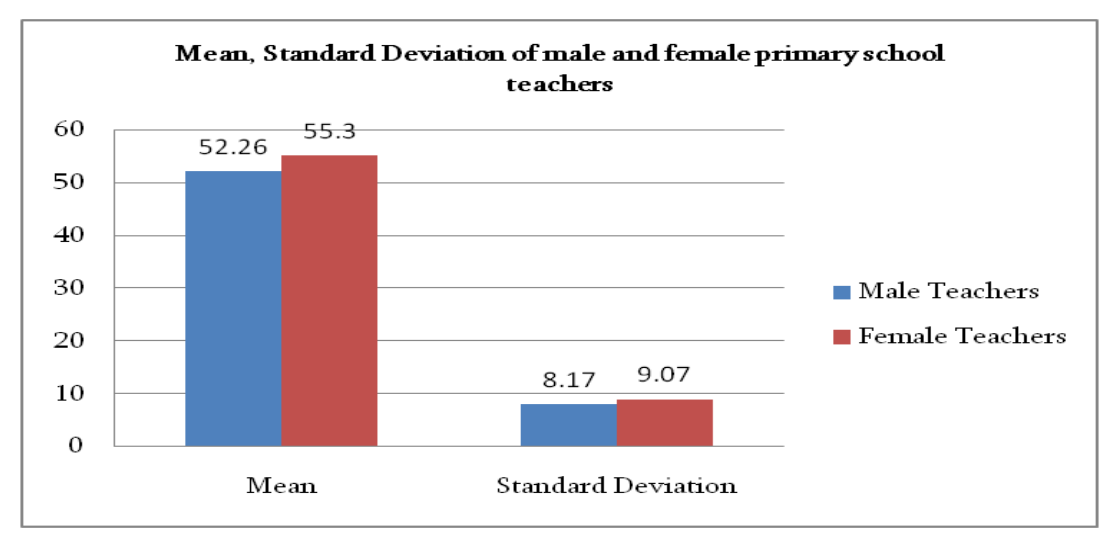

Fig. 3 Mean standard devition of male and female teacher from primary school 
Performance on the Work-related Stress and Job contentment of Primary School Teachers of Government and Private Sectors

The above table demonstrates value of t 0.15 that is not female primary teachers from school is greater when significant at the level of 0.05 . This infers that stress among compare with primary male schoolteachers.

Table. 4 Table showing the level of teachers stress for male as well as for government primary schools

Mean; Standard Deviation \& value of t female as well as male teachers from Government primary schools

\begin{tabular}{|l|l|l|l|l|l|l|}
\hline Sno & Category & Sample & Mean & $\begin{array}{l}\text { Standard } \\
\text { Deviation }\end{array}$ & t-value & $\begin{array}{l}\text { Level } \\
\text { significance }\end{array}$ \\
\hline 1 & Male & 75 & 45.66 & 2,1 & 0.01 & Not significant \\
\hline 2 & Female & 75 & 47.2 & 1.91 & & \\
\hline
\end{tabular}

Figure 4 shows the mean standard devition of male as well as teachers from female from the primary school run by the government.

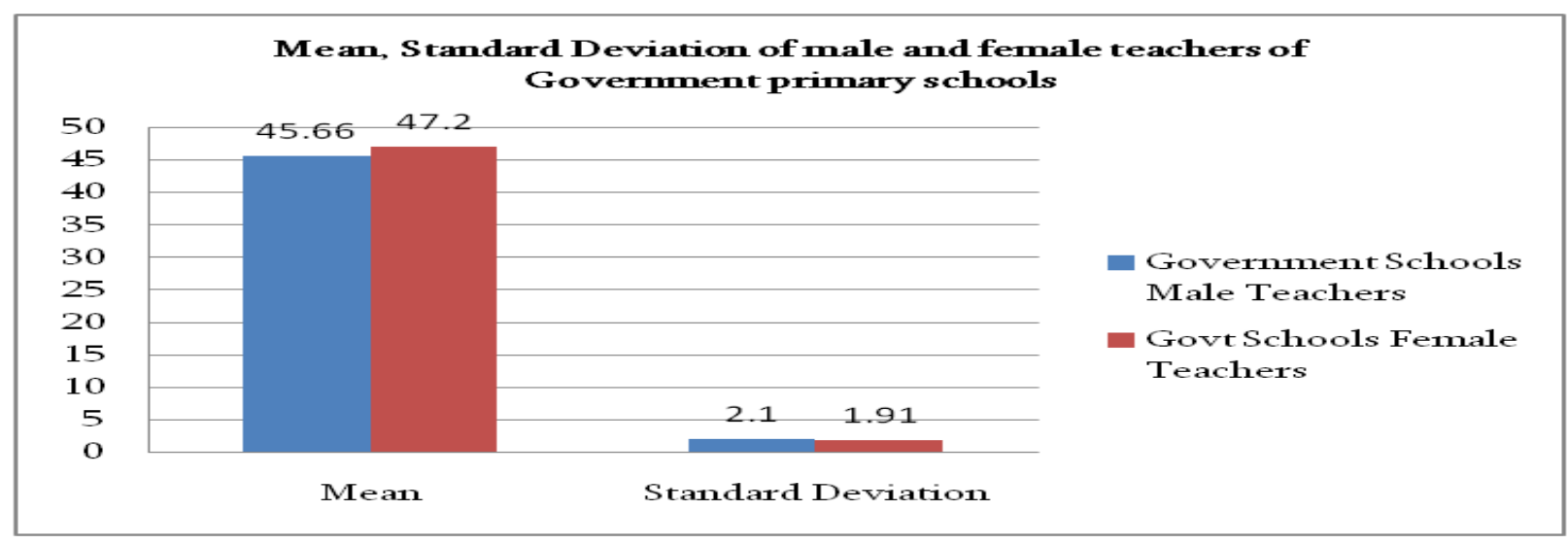

Fig. 4 Mean standard devition of male as well as teachers from female from the primary school run by the government

The result shows that " $\mathrm{t}$ " value is 0.01 that is not noteworthy observed by the primary school teachers compared to the at the level of 0.05. This infers that the stress is more government school teachers.

Table. 5 Table indicating the stress level of male and female teachers of private primary schools.

Mean and Standard Deviation \& value of $\mathbf{t}$ female and male teachers from primary

\begin{tabular}{|c|c|c|c|c|c|c|}
\hline Sno & Category & Sample & Mean & $\begin{array}{c}\text { Standard } \\
\text { Deviation }\end{array}$ & t-value & $\begin{array}{c}\text { Level of } \\
\text { significance }\end{array}$ \\
\hline 1 & Male & 75 & 60.12 & 4.01 & 1.4 & Not significant \\
\hline 2 & Female & 75 & 64.44 & 2.92 & & \\
\hline
\end{tabular}

Figure 5 shows the mean and standard devition of private male and female primary teachers

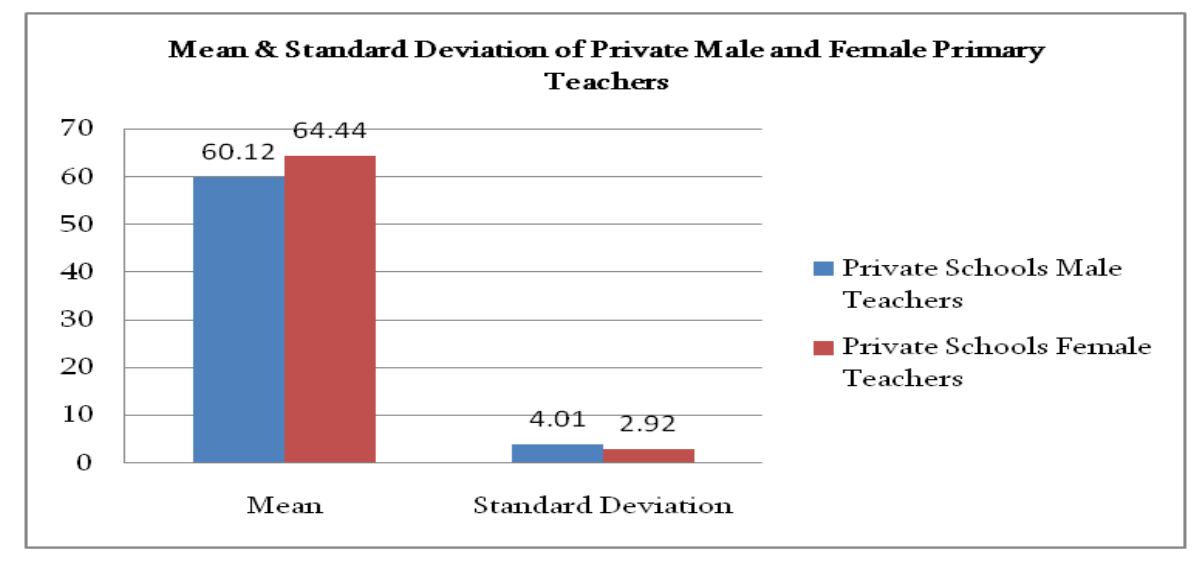

Fig. 5 Mean and standard devition of private male and female primary teachers

The result shows that " $\mathrm{t}$ " value is 1.4 , that is not noteworthy level of 0.05 . This infers that the stress is more observed by the female teachers compared to male teachers of private schools. 
Table. 6 Table showing the stress level of teachers from primary private sector.

Mean-Standard Deviation; t-value of Government as well as teachers from primary school through private sectors

\begin{tabular}{|c|c|c|c|c|c|c|}
\hline Sno & Category & Sample & Mean & $\begin{array}{c}\text { Standard } \\
\text { Deviation }\end{array}$ & t-value & $\begin{array}{c}\text { Level of } \\
\text { significance }\end{array}$ \\
\hline 1 & Government & 75 & 44.16 & 2.09 & 4.44 & 0.01 \\
\hline 2 & Private & 75 & 60.32 & 3.99 & & \\
\hline
\end{tabular}

Figure 6 shows the mean and standard devition from the male school teachers from private sector as well as government primary

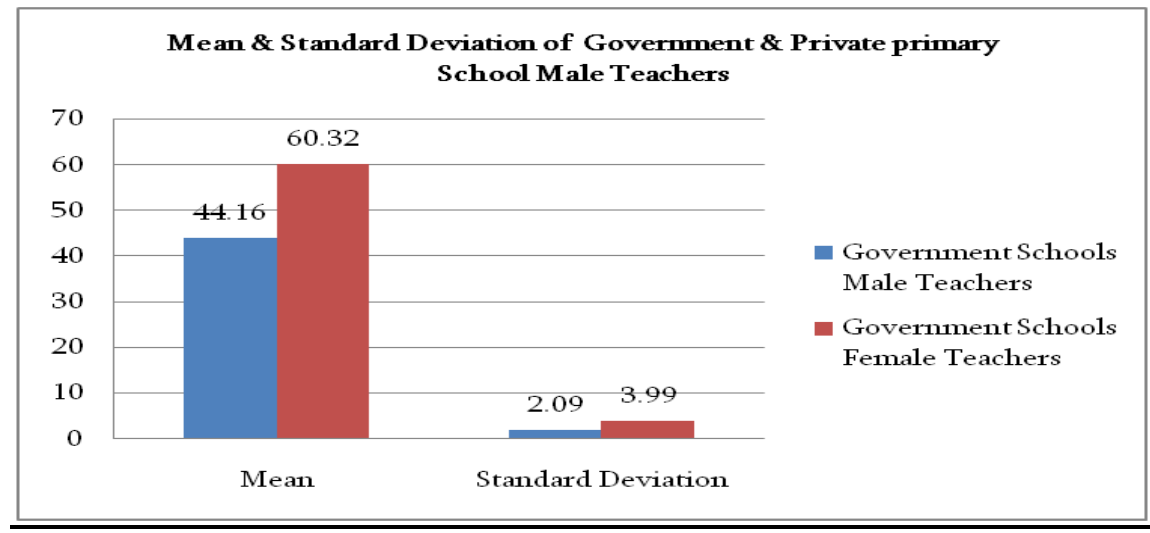

Figure. 6 Mean and standard devition from the male school teachers from private sector as well as government primary

The result shows that " $t$ " value is 4.44 which not noteworthy at the of 0.05 level. This infers that the stress is more observed by the female teachers compared to male teachers of government schools.

\section{CONCLUSION}

It is concluded that the teachers working in the government sectors are found to be very much satisfied than the ones employed in private schools, the fact being that the job security is more high and much safer in the government schools than the private schools. Apart from the job security, government school teachers are satisfied with the remuneration in terms of intrinsic rewards and extrinsic rewards which makes the teachers of the government schools more satisfied. Intrinsic and Extrinsic rewards seem to be a very pale factor in the private sectors. This pulls down the morale of the teachers working in the private schools. Poor Decision making policies, No proper chain of control and unbiased promotion policies also add fuel to the fire amongst the private school teachers.

These mentioned factors are found disturbing the minds of the teachers of the private schools which leads to more distress leading them to more absenteeism, non-cooperation and non-involvement in work.

The detections of the study have revealed that the teaching profession is found to be highly stressful supporting the study of Olivier \& Venter, 2003.

\section{REFERENCES}

1. Raj,T.,\&Lalita (2013). Job Satisfaction among Teachers of Private and Government School: A Comparative Analysis. International Journal of Social Science \& InterdisciplinaryResearch, 2 (9).

2. Mabekoje, S. O. (2009). Gender Differences in Job Satisfaction among Secondary School Teachers. African Journal of Research in Personnel and Counselling Psychology, 1 (1), 99-108
3. Achanta, S., \& Reddy, V. D. (2014). Job Satisfaction Among Primary School Teachers In Krishna District. PARIPEX - INDIAN JOURNAL OF RESEARCH, 3 (12), 95-96.

4. Gakhar, S., Markanda, S., Pautela, R. Job Satisfaction Among Primary, Middle and Secondary School Teachers. Journal of the Institute of Educational Research, Vol.8, No.2, May 1984.

5. Ahmad, N., Raheem, A. and Jamal, S. (2003). Job satisfaction among school teachers. The Educational Review, 46(7),123-126

6. Anbuchelvan, C., 2010, "Occupational Stress of High School Teachers", EduTracks, 9 (9), pp. 31-33. Bachkivora, T. (2005) Teachers stress and personal values: An exploratory study. School Psychology International, 26(3), 340-352.

7. Jennifer Hart, "Study finds women faculty experience more stress than men in higher education", Black Issues in Higher Education, 24th March, 2005,pp.43-54.

8. R. Ravichandran and R. Rajendran ,“ Perceived Sources of Stress Among the Teachers" , Journal of the Indian Academy of Applied Psychology 2007, Vol. 7 Iss. 4.

9. ShilpiGoyaland and RuchiGoel, "Stress Level Among Teachers of Public and Private Sector Institutions : An Empirical Investigation", International Journal Of Indian Culture and Business Management Vol. 2 No. 4, 2009

10. Jeyaraj S.S. (2013). Occupational stress among the teachers of the higher secondary schools in Madurai district, Tamil Nadu. IOSR Journal of Business and Management, 7(5), 63-76.

11. Reddy G.L. and Anuradha R.V. (2013). Occupational stress of higher secondary teachers working in Vellore district.International Journal of Educational Planning \& Administration, 3 (1), 9-24.

12. Bindu, C.M. (2007). Relationship between Job Satisfaction and Stress Coping Skills of Primary School Teachers. Edutracks, 6(5), 34-36.

13. Gaziel, H.H.(1993).Coping with Occupational Stress among Teachers: a cross- cultural study. Comparative Education, 29(1), 67-79.

14. Muthu velayutham, C. and Mohanasundaram, H. (2012). A Study on the Impact of Occupational Stress among Teachers on Job Satisfaction and Job Involvement- An Empirical Study.European Journal of Social Sciences, 30(2), 339-351.

15. Reglin, G. \&Reitzammer, R.A. (1997). Dealing with the stress of teachers. Education. 118(4), 590-597.

16. Satvinderpal (2011). Job Satisfaction and Occupational Stress among School Teachers: A Correlational Study. Shodh, Samikshaaur, Mulyankan 3(34), 49-50. 